[Original]

\title{
Biological Marker of Furfural, Chemicals without Administrative Control Level
}

\author{
Yasuo Morimoto', Hajime Hori², Toshiaki Higashi ${ }^{3}$, Hiroko Nagatomo', \\ Yoshiyuki Hino ${ }^{4}$, Atsushi OHSATO ${ }^{3}$ and Bungo UCHINO 3 \\ 'Department of Occupational Pneumology, Institute of Industrial Ecological Sciences, University of \\ Occupational and Environmental Health, Japan. Yahatanishi-ku, Kitakyushu 807-8555, Japan \\ ${ }^{2}$ Department of Environmental Management I, School of Health Sciences, University of Occupa- \\ tional and Environmental Health, Japan. Yahatanishi-ku, Kitakyushu 807-8555, Japan \\ ${ }^{3}$ Department of Work Systems and Health, Institute of Industrial Ecological Sciences, University of \\ Occupational and Environmental Health, Japan. Yahatanishi-ku, Kitakyushu, 807-8555 Japan \\ ${ }^{4}$ Occupational Health Training Center, University of Occupational and Environmental Health, \\ Japan. Yahatanishi-ku, Kitakyushu 807-8555, Japan
}

Abstract : Furfural, a colorless liquid used in solvent-extraction processes, petroleum refining and as a rubber additive, has been assigned an occupational exposure limit of $2.5 \mathrm{ppm}$ by the Japan Society for Occupational Health, but an administrative control level for furfural has not been established. In order to conduct effective occupational health management in workplaces where furfural is used, we measured furfural concentrations in working environments and collected urine samples to measure furoic acid levels (one of the principal metabolites), which act as a biomarker of exposure to furfural. The measurements of airborne concentrations in a working environment where furfural or a solution containing furfural was handled were made in 2004. Workers answered a questionnaire on working conditions, urine samples were collected at the end of the workshift, and furoic acid in the urine was measured by gas chromatography/flame ionization detector (GC/FID). The ambient concentrations of furfural during the period were $2.1 \mathrm{ppm}$ in a mixer room and $1.6 \mathrm{ppm}$ in a filling room. The mean concentrations of furoic acid in the workers' urine were $7.7 \pm 7.8$ $\mathrm{mg} / \mathrm{g}$-creatinine in summer and winter, respectively (normal range: $3-60$ $\mathrm{mg} / \mathrm{g}$-creatinine). The average exposure to furfural per month calculated by multiplying the concentration in the working environment by working hours for a month was $86.4 \pm 108.6 \mathrm{ppm}$ hours $/$ months (mean \pm standard deviation) (range; $0-336 \mathrm{ppm}$ hours/month). The relationship between average exposure to furfural and furoic acid in the urine was analyzed by simple linear regression analysis and a positive correlation was found. These findings suggest that furoic acid in urine is useful for biological monitoring of exposure to furfural, and that the measurement of both furfural in the environment and furoic acid in the urine are beneficial in occupational health management of furfural.

Key words : furoic acid, furfural, biomaker, uria, worker.

(Received 25 October 2006, accepted 27 March 2007) 


\section{Introduction}

Furfural is a volatile, liquid organic chemical at normal temperatures that is produced from sugar-cane and corn cobs and used for oil refining, refractories, medical products and perfume; 2400 tons of furfural is imported to Japan annually $[1,2]$. The effects of furfural on health, from animal experiments, are irritation of outer organs such as the skin, eyes and airway caused by acute exposure, and allergic sensitization, light-sensitive disorder, central nervous system disorder, hepatorenal disorder, and blood and bone marrow disorders caused by chronic exposure [3]. Acute effects by high concentration exposure were reported in workers $[4,5]$, however, long-term research into chronic disease and oncogenesis has not been reported, and the chronic effects of furfural on human beings is a matter of concern. The occupational exposure limit of furfural is $2.5 \mathrm{ppm}$ (Japan Society for Occupational Health, 2005). However, since the administrative control level has not been established and working environment management is dependent on the self-management of each corporation [6], occupational health may not be fully managed in this case.

Even this uncontrolled substance needs countermeasures to be taken if there is a possibility of exposure. As with other organic solvents, the environmental measurement of furfural can be conducted by the solid collecting method with an activated charcoal tube. On the other hand, for biological monitoring that estimates exposure in vivo, furoic acid in urine, a metabolite of furfural, can be measured by gas chromatography/ flame ionization detector (GC/FID).

The present study examined the environmental measurement and the workers' history of exposure to furfural, and a confirmed consistency between the exposure and furoic acid in urine, in order to seek possibilities of occupational health management of furfural and biological monitoring of furfural in workplaces.

\section{Methods}

\section{Measurement of furfural concentration in the working environment}

The workplaces in the present study were a mixer room where powder material and furfural are mixed, and a filling room where mixed materials are filled. In the former process, workers mixed raw materials of brick with furfural in mixer, and in the latter, workers filled molds with the raw material with furfural and made bricks with high pressure. According to a sampling of the working environment measurement standard [ 7 ], measurement points were decided and working environment measurement was conducted once a year in 2004. The solid collecting method using an activated charcoal tube was used to sample furfural with aspiration flow rate of $0.5 \ell / \mathrm{min}$ for 10 minutes at each measurement point. After the collection, adsorbed furfural was desorbed with carbon disulfide, and furfural concentration in the air was determined.

\section{Workers}

All the workers were male, and the number of workers treated with furfural were 45 
(Table 1). They had a special medical examination twice a year, and answered the questionnaire (presence of subjective symptoms such as irritation, numbness, dry skin, itching, congestion, cough, headache, etc, working hours and frequency of dealing with furfural, confirmation of work place). The urine was collected after the end of work on the same day or several days later, and we measured the concentration of free furoic acid, a furfural metabolite. Before the special medical examination for furfural, these were fully explained and agreed to by the safety and health committee and workers.

\section{Special medical examination for furfural}

A special medical examination for furfural was conducted in the summer and winter (Table 1). The average age of the workers was $44.3 \pm 9.4$ years old. The questionnaire was delivered to workers in advance and confirmed by industrial health staff during medical examinations. The average exposure to furfural per month was calculated as follows: (concen

Table 1. Furoic acid in urine of workers in furfural-using industry

\begin{tabular}{ll} 
Health examination & Summer (2004) \\
\hline Participants (N) & 45 \\
Furoic acid in urine (mg/g-cr.) & $7.7 \pm 7.8$ \\
Over reference value (\%) & 0 \\
& \\
Workplace where furfural is used (ppm) & \\
$\quad$ Mixer room & 2.1 \\
Filling room & 1.6 \\
\hline
\end{tabular}

*: Percentage of workers with over reference value per all workers in the furfural-using industry

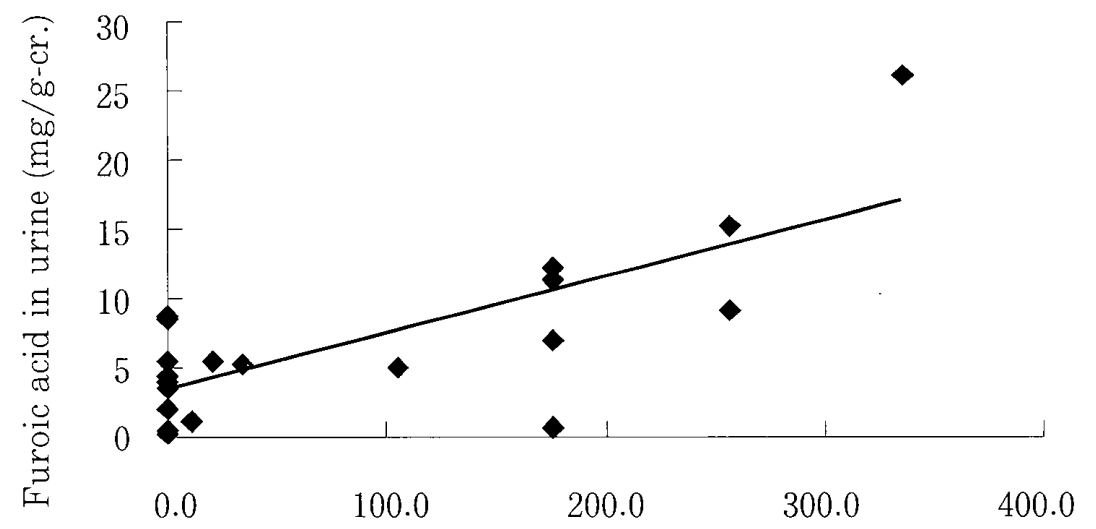

Average exposure per month to furfural (ppm hours/month)

Fig. 1. Correlation between furoic acid in urine and average exposure to furfural per month.

- : Measured value. 
tration in working environment) $\times$ (working days in a month) $\times$ (working hours in a day) (Fig. 1). The working hours for the workers who did not directly handle furfural were 0 .

\section{Biological samples}

After 8 hours of working, urine samples of the participants were collected in the inhouse clinic, were frozen, and were mailed through the West Japan Association of Industrial Health Institutes to Matsushita Science Center of Industrial Hygiene. The urine samples were methyl-esterified, extracted with n-hexane, and measured to determine the concentration of free furoic acid, a furfural metabolite, by GC/FID (Yokogawa GC5890, column: Spelcowax-10, detector: FID, column; He $20 \mathrm{kPa}, 2.4 \mathrm{ml} / \mathrm{min}$ ). The lower limit of detection for 2 -furancarboxylic acid and 3-furancarboxylic acid was $0.2 \mathrm{mg} / \ell$ and $0.05 \mathrm{mg} / \ell$, respectively.

\section{Statistical analysis}

Simple correlation was examined by Excel (statcel 2) to analyze the correlation between the estimated average exposure to furfural and furoic acid in the urine.

\section{Results}

Furoic acid in urine

The average concentration of furoic acid in the urine of the workers was $7.7 \pm 8.7 \mathrm{mg} / \mathrm{g}$ $\mathrm{cr}$. in the summer and winter, respectively (reference range 3-60 $\mathrm{mg} / \mathrm{g}$-cr.) (Table 1). Seasonal variation was not found, while the value was slightly higher in the summer than in the winter. No workers whose concentration was higher than the reference value $(60 \mathrm{mg} / \mathrm{g}$ cr.) were observed.

A value $>2.5 \mathrm{ppm}$ (the occupational exposure limit) was not obtained in the filling room or mixer room in a sampling.

\section{Estimated average exposure to furfural}

Among 45 workers, data on 22 workers who filled in a sufficient quantity of working hours and frequency of dealing with furfural in the questionnaire were used. The estimated average exposure to furfural per month in the summer was $86.4 \pm 108.6 \mathrm{ppm}$ hours/months (mean \pm standard deviation) (range; 0-336 ppm hours/months).

The relationship between furoic acid in urine and estimated personal exposure to furfural

The simple regression analysis resulted in furoic acid in urine $=0.04 \times$ average exposure to furfural per month +3.20 with positive correlation $(P<0.01)$ (Fig. 1). 


\section{Discussion}

Furfural (2-furaldehyde) is an aldehyde that has a furan ring structure. Generally, chemical substances taken into the living body undergo various changes, such as oxidation, reduction and conjugation by drug metabolizing enzymes, to be excreted eventually. As aldehydes are known to be changed into carboxylic acid by oxidation, furoic acid in urine was chosen as a metabolite of furfural in the present study [8-10]. This furancarboxylic acid is an oxidant of furfural. This oxidant was chosen as a measuring target because oxidation of chemical substances is a generally recognized major reaction in vivo, and furfural is easily auto-oxidized by air and light in the environment. In fact, furfural turns red in the workplace, showing its high sensitivity to oxidation. Therefore, when furoic acid in the urine was measured and personal average exposure to furfural was estimated by working environment measurement, a positive correlation between them was found. This may show that at least a part of the exposed furfural is metabolized as furancarboxylic acid. In future, we will consider this analysis with the alkaline hydrolysis step in order to improve recovery of the furoic acid [9].

In Japan, working environment measurement at fixed points is mandatory in designated workplaces. Although furfural in the present study is not included in the mandatory working environment measurement, A sampling and B sampling of furfural at fixed points were conducted in accordance with the Japanese working environment measurement standard to estimate the exposure of workers to furfural. However, it has been pointed out that a value obtained by working environment measurement at a fixed point does not always correspond to personal exposure. For this reason, measurement of personal exposure by personal sampler rather than the fixed point method is generally conducted in Europe and the U.S. [11]. However, there is no regulation for measurement of personal exposure in Japan. As shown in the figure, there was a correlation between the average exposure to furfural estimated from working environment measurement and the metabolite in the urine, and a stronger correlation may be obtained from the analysis of personal exposure and the metabolite in urine.

The possible exposure routes of furfural are the transairway and transdermal. Since workers wear a gas protection respirator when they are working, the transairway exposure is probably small. However, the protection factor by the National Institute for Occupational Safety and Health (NIOSH) is 10 for half-face type gas protection respirators, so that $10 \%$ of furfural may go through the respirator to result in transairway exposure. Moreover, although the breakthrough time after absorption in the gas protection mask is unknown for furfural, the possibility of transairway exposure to furfural cannot be ignored because longterm use of the respirator may lead to breakthrough by the vapor. In the case of transdermal exposure, the following suppositions were made. Furfural is vaporized in a high-temperature kiln in both workplaces, and cools in the environment to condense into mist that on contact with the skin is absorbed into the body. Higher concentrations in the environment make it easier to condense into mist. Moreover, as workers sweat due to high temperature, furfural mist is more likely to adhere to their skin. It is unknown which one of these two routes largely contributes to exposure, so that further study is needed to clarify 
this, as well as to investigate the effects of using a respirator.

There was no seasonal variation of furancarboxylic acid in the urine. This may be partly affected by annual production.

There may be various modifiers in biological monitoring of exposure to furfural, e.g., food, because furfural is an extract of grain; medication, because furfural is used in some drugs; and various other factors. However, the details of furfural metabolism are unknown at present, and accordingly it is unknown if one factor strongly contributes as a modifier compared with others, or whether there is even a modifier or not. However, it is suggested that there was no modifier that contributes largely, because furoic acid in the urine correlated with the exposure level estimated from the working environment measurement. Further studies are needed to take account of lifestyle and other factors to identify the modifiers.

The occupational exposure limit of 8 hour exposure was $2.5 \mathrm{ppm}$ [12]. Korenman et al [13] reported the environmental level in a workplace of $1.8-13.5 \mathrm{ppm}$, and our data was similar to their lower value. They also reported that there were workers with headache, throat irritation and bloodshot eyes. Workers who had the same complaint were found in the present study, and these symptoms also indicate that the exposure level in our study is the same as or lower than that of the report by Korenman et al [13].

We conducted the measurement of furfural concentration in the working environment in a workplace, an interview with the workers at the same workplace during working hours, and the measurement of furancarboxylic acid in the urine of the workers. As a result, the furfural concentration in the environment was $1.6 \mathrm{ppm}$ and $2.1 \mathrm{ppm}$. A positive correlation was found between the average exposure to furfural estimated from its concentration in the environment and furoic acid in the urine. These findings suggest that furoic acid in urine is useful for biological monitoring for exposure to furfural, and that the measurements of both furfural concentration in the environment and furoic acid in urine are beneficial for occupational health management of furfural.

More than 57,000 chemical substances are used in workplaces in Japan (Industrial Hygiene Handbook 2004). Of them, only 93 substances, mainly consisting of substances such as organic solvents (Type I and II), specified chemical substances (Type I and II) and lead, in addition to dusts, are subject to working environmental measurement. Besides, only 82 of them have administrative control level that enables the evaluation of the working environment. Since it is not mandatory to conduct working environment measurement with respect to substances other than the above, the actual state of the working environment has not been grasped. Legal specific medical examinations are for the most part limited to organic solvents, specified chemical substances, lead, tetraalkyl lead, and dusts, and are seldom or never conducted for operations that handle substances other than these.

While substances other than the above are used in workplaces, the health effect of these uncontrolled substances are a cause for concern. Recently, an industrial safety and health management system has been introduced, and each corporation is expected to take countermeasures against risks in workplaces irrespective of the lack of regulation. However, this system is not extensively practiced. As shown in the present study, even a substance 
without a specified administrative control level, when the occupational exposure limit is recommended for such substance, the working environmental measurement and evaluation of the substance can be conducted based on the occupational exposure limit. Moreover, even a substance without recommended BEI can be covered by biological monitoring by extrapolating the metabolic pathway from its chemical structure. We will examine not only furfural but also various other chemical substances by a similar approach in further studies.

\section{Acknowledgement}

We thank Mrs. Y. Ooba and Ms. J. Nakashima for their excellent assistance with some of the present study.

\section{References}

1. The Chemical Daily Co., Ltd. (2003): Furfural 833. Kagakusyouhinn p 14303

2. Windholz M (1983): An encyclopedia of chemicals, drugs, and biologicals (10th). the Merck Index Merk Co., Rahway p 614

3. NIOSH (1978): Occupational health guideline for furfural Cincinnati. NIOSH: $1-5$

4. Ubaidullaev R (1961): Data substantiating the maximum permissible concentration of furfural in atmospheric air. Gig Tr Prof Zabol 26: 3

5. Dunlop AP \& Peters FN (1953): The Furans. ACS Monograph series 119. Reinhold, New York p 292

6. Japan Industrial Safety and Health Association (2005): Administrative control level. General guidebook on industrial health 2005. Japan Industrial Safety and Health Association, Tokyo pp162-163

7. Japan Industrial Safety \& Health Assoclation (2006): Industrial safety and health law. General guidebook on industrial health (2006). Japan Industrial Safety \& Health Association Tokyo pp $158-159$

8. Flek J \& Šdivec V (1978): The absorption, metabolism and excretion of furfural in man. Int Arch Occup Environ Health 41: 59-168

9. Tan ZB , Tonks CE , O'Donnell GE \& Geyer R (2003): An improved HPLC analysis of the metabolite furoic acid in the urine of workers occupationally exposed to Furfural. Journal of Analytical Toxicology 27: 43-46

10. Šedivec V \& Flek J (1978): Biologic monitoring of persons exposed to furfural vapors. Int Arch Occup Environ Health 42: 41-49

11. ACGIH (1997): TLVs ${ }^{\circledR}$ BELs ${ }^{\circledR}$. Threshold limit values for chemical substances and physical agents biological exposure indices. ACGIH, Cincinnati pp 3-14

12. Japan Society for Occupational Health (2004): Recommendation of occupational exposure limits (2004-2005). J Occup Health 46: 329-344

13. Korenman IM \& Resnik IB (1930): Furfural als gewerbliches gift und seine bestimmung in der luft. Arch Hyg 104: 344 
管理濃度として規定されていない化学物質の生物学的モニタリングの検討 ーフルフラール (furfural) についてー

森本 泰夫 ${ }^{1}$, 保利 - ${ }^{2}$, 東 敏昭 ${ }^{3}$, 長友 寛子 ${ }^{1}$, 日野 義之 ${ }^{4}$, 大里 厙 ${ }^{3}$, 内野 文吾 ${ }^{3}$

'産業医科大学 産業生態科学研究所 呼吸病態学研究室

2 産業医科大学 産業保健学部 第一環境管理学講座

3 産業医科大学 産業生態科学研究所 作業病態学研究室

産業医科大学 産業医実務研修セン夕ー

要

旨：フルフラールは無色透明な液体で, 石油精製や溶剂, ゴム添加剂などに使用され日本産業衛 生学会から許容濃度が2.5 ppm と勧告されているが, 管理濃度は設定されていない.フルフ ラールを使用する作業場の労働衛生管理を有効に行うため, フルフラールの作業環境濃度 と曝露指標マーカーとして尿中のフルフラールの代謝産物である尿中フランカルボン酸を 測定し, 平成16 年においてフルフラール取り扱い職場にて作業環境濃度を測定した. 同作業 者を対象に作業時間の問診を行い, 就業後に尿を採取しHPLCにて尿中のフランカルボン 酸の測定を行った. 環境中のフルフラール濃度は期間中の濃度は1.6 ppmから $2.1 \mathrm{ppm}$ であっ た。作業者の尿中カルボン酸の平均濃度は $7.7 \mathrm{mg} / \mathrm{g}$-クレアチニン $(3-60 \mathrm{mg} / \mathrm{g}$-クレアチ ニン)であった.作業環境濃度に 1 ケ月間の作業時間を乗じた平均累積嚗露量(cumulative exposure to furfural )推定值は, $86.4 \pm 108.6 \mathrm{ppm}$ 時間/月 $(0-336 \mathrm{ppm}$ 時間/月)であり, これを尿中フランカルボン酸と単回帰分析を行い, 平均累積曝露量と尿中フランカルボン 酸は正の相関を示した.これらのことは尿中フランカルボン酸がフルフラール作業におけ る曝露量の推定に有効でありバイオロジカルモニタリングの曝露指標になりうること,さ らに環境中のフルフラール濃度測定と尿中フランカルボン酸の測定はフルフラールの労働 衛生管理に有効であることを示唆した。

キーワード：フルフラール, 化学物質, バイオロジカルモニタリング, 尿, フラルカルボン酸.

J UOEH（産業医大誌）29 (2)：141-148 (2007) 